Jaromír Krško

UDK 81'373.21(439.22)

Univerzita Mateja Bela

DOI: 10.4312/linguistica.55.1.47-57

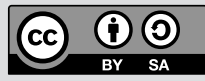

v Banskej Bystrici*

\title{
VPLYV PREDSLOVANSKÝCH KONTAKTOV NA HYDRONYMIU SLOVENSKA
}

Dejinné udalosti sa neustále opakujú, menia sa len l'udia, miesto a čas. Naša súčasnost' potvrdzuje to, čo sa odohrávalo v minulosti pred stovkami tisíc rokov, pred tisíckami rokov či pred stovkami rokov. Ludia, tak ako dnes, aj v minulosti neustále putovali a hl'adali lepšie podmienky pre život a svoju budúcnost'. Hoci v minulosti nebol počet obyvatel'ov taký vysoký ako dnes, teda ani osídlenie krajiny nebolo také husté, málokedy sa stalo, aby jednotlivé etniká prichádzali na „územie nikoho“. Väčšinou tak dochádzalo ku kontaktom medzi pôvodným a prichádzajúcim obyvatel'stvom, prirodzene dochádzalo ku konfliktom, ktorých podoby a výsledky boli rôzne.

Etnické kontakty mali vplyv aj na jazyky týchto etník, dochádzalo ku vzájomnému ovplyvňovaniu a preberaniu časti lexiky. Prichádzajúce etniká sa museli orientovat’ v novom prostredí, museli identifikovat' a diferencovat' dôležité orientačné body, medzi ktoré patria predovšetkým vrchy, pohoria a vodné toky. Vo všeobecnosti platí, že najväčšie toponymické objekty majú pôvod svojho názvu vel'mi starý a k takýmto objektom bezpochyby patria aj vel'ké rieky. Tie boli nielen prekážkou pri migrovaní, ale zároveň aj dôležitou hranicou, ktorá okrem prirodzenej ochrany poskytovala aj vodu potrebnú pre život a potravu. Smer pohybu etník bol predovšetkým v smere prirodzených nížin a proti prúdu riek, takže k etnickým kontaktom dochádzalo predovšetkým v deltách vel'kých tokov.

Územie Slovenska leží v strede Európy a už v dávnej minulosti viedli týmto priestorom mnohé dôležité obchodné cesty. Známa Jantárová cesta viedla od Baltského mora do Istrie, Byzancie, Dalmácie, týmto územím viedla dôležitá Solná cesta a množstvo menších obchodných ciest.

Územie strednej Európy obývali pred Slovanmi predovšetkým germánske kmene Ostrogótov, Langobardov, Herulov, Gepidov, Kvádov a mnoho iných kmeňov. Neskôr prišli do týchto oblastí Huni. Práve výboje Hunov pod vedením Attilu spôsobili vel'ké migračné pohyby v Európe. „Príchod Hunov do Európy znamenal predel, či dokonca zlom medzi dvoma epochami. Nielenže sami strhli k presunom iné kmene, ale zo strachu pred nimi opustili svoje sídla mnohé iné národy. Tým prvým bol už spomínaný presun Gótov na druhú stranu Dunaja, d’alší pohyb, ktorý začal v roku 406, ul'ahčil dezintegráciu

* Tajovského ulica 51, K143, 97400 Banská Bystrica, Slovenská republika; jaromir.krsko@ umb.sk 
Západorímskej ríše. Nadvláda Hunov taktiež urýchlila proces rozkladu starej rodovej spoločnosti a vzrast vplyvu bojovníckej zložky... Prítomnost' Hunov definitívne ukončila éru rímskych légií.“ (Bystrický 2008: 10)

Archeologické výskumy dokázali, že Slovania prišli na toto územie na prelome 5. a 6. storočia nášho letopočtu, staršie pramene datujú ich príchod na prelom 4. a 5. storočia (pozri Ratkoš 1965: 11). „Rozbor niektorých písomných prameňov pomerne bezpečne upozorňuje na prítomnost' Slovanov na danom území najneskôr v prvej polovici 6. stor.“ (Fusek 2002: 24). Ide predovšetkým o nápis vytesaný roku 558 na počest' biskupa Martina z Tours na počest' svätenia baziliky, dôležitým prameňom je aj Prokopiov opis osudov uchádzača o longobardský trón Hildigisa, ktorý ušiel v roku 535 k Slovanom a dielo Getica neskororímskeho spisovatel'a Jordana (Fusek 2002: 24). „Vo včasnostredovekom období na Slovensku rozoznávame dve fázy s predelom na prelome 6. a 7. stor. Hornú hranicu mladšej fázy tohto obdobia ohraničuje počiatok avarského záboru južných, naddunajských častí západného Slovenska, prejavujúci sa zakladaním pohrebísk v polovici 7. stor. Vo vleku Avarov azda prišli aj d’alšie skupiny Slovanov.“ (Fusek 2002: 25)

K chápaniu predslovanskej motivácie slovenských hydroným môžeme pristupovat' dvojako. Vzhl'adom na datovanie príchodu Slovanov na naše súčasné územie môžeme pracovat's názvami spred tohto obdobia. $\mathrm{V}$ gréckych, rímskych prameňoch sa vyskytujú názvy riek Dunaj, Morava, Tisa. Nie je však isté, či ide o označenie častí tokov zo slovenského územia. Ich podoby však prevzali naši predkovia a tieto názvy sa včlenili do slovenskej hydronymickej sústavy. Z územia Slovenska máme spred obdobia príchodu Slovanov dochovaný len presný zápis rieky Hron, ktorý pochádza z pera rímskeho cisára Marka Aurélia z rokov 166 - 180 Granoua. V tejto otázke však súhlasíme $\mathrm{s}$ názorom historika $\mathrm{B}$. Varsika, ktorý správne uvažuje o tom, že ak „Marcus Aurélius bojoval v druhom storočí n. 1. pri dolnom toku rieky Hrona a zapísal nám názov rieky ako Granoua, ktorý novoprichádzajúci Slovania prevzali od predchádzajúceho obyvatel'stva vo forme Gron (a podobne prevzali aj názov rieky Moravy), t’ažko môžeme predpokladat', že by Slovania neboli našli nejaké zvyšky starého predslovanského obyvatel'stva aj pri dolných tokoch rieky Váhu, Nitry a Ipl'a. Ved' rieka Ipel' vteká do Dunaja len niekol'ko kilometrov východne od ústia rieky Hron do Dunaja“ (Varsik 1989: 7). Žial', najstaršie doteraz nájdené zápisy najdlhšej slovenskej rieky - Váhu (podobne ako iných slovenských riek) pochádzajú zo začiatku 12. storočia (1111 flumen Vvaga, 1113 aqua $V v a c$ ), teda až z obdobia prítomnosti Slovanov v tomto priestore. V doterajších historických výskumoch máme preto z predslovanského obdobia najzretel'nejšie preukázaný len zápis rieky Hron v už spomínanom zápise rímskeho cisára Marca Aurélia z obdobia rokov 166 - 180 (pozri aj Krško 2008: 78 - 80). Ďalším argumentom B. Varsika o predslovanskom pôvode viacerých vel'kých vodných tokov Slovenska je ich nejasná a nejednoznačná etymológia, na rozdiel od menších vodných tokov, v ktorých dominuje predovšetkým všeslovanský apelatívny základ.

Druhým prístupom v oblasti výskumu predslovanských východísk slovenskej hydronymie je pripomenutie názorov jazykovedcov, etymológov a historikov o predslovanských pôvodoch hydroným (predovšetkým germánskych, keltských), ktoré existujú 
paralelne popri názoroch o slovanskom, či slovenskom pôvode. V prípade názorov o indoeurópskom východisku názvu možno polemizovat' o tom, či názov prevzali Slovania od predchádzajúceho etnika, alebo sa vyvinul v ich jazyku, pretože prevažná čast' etník európskeho priestoru má indoeurópske jazykové východiská.

Hydrologicky patrí územie Slovenska do povodia Dunaja, pretože 96 percent všetkých vodných tokov odvodňuje Dunaj a zvyšné toky z povodia Popradu a Dunajca na severe Slovenska ústia do rieky Visla.

Druhá najväčšia európska rieka Dunaj $(2857 \mathrm{~km})$ vzniká sútokom riek Breg a Brigach v Nemecku, preteká desiatimi štátmi a ústi do Čierneho mora. Územím Slovenska preteká Dunaj v dížke $182 \mathrm{~km}$ od Bratislavy po Štúrovo, kde sa stáča na juh a tečie do Mad'arska. Dunaj sa v historických listinách spomína už v prvom storočí nášho letopočtu. Píše o ňom rímsky cisár Gaius Julius Caesar, ktorý ho zapísal ako Danuvius. Jordanes v práci De origine actibus Getarum spomína tento tok pod názvom Danubius a stotožňuje ju so starším gréckym názvom Ister (Varsik 1989: 15). Podobu Ister (latinsky Istros) je vyložená v publikácii Zeměpisná jména Československa ako „valiaca sa rieka“ (pozri Lutterer - Majtán - Šrámek 1982: 91). Mladšie zápisy Dunaja z oblasti dolného toku pochádzajú z pera arabského cestopisca a geografa Abú Saida Gardízího (zomrel roku 1039), ktorý opísal moravských Slovanov a starých Mad’arov. „V blízkosti Slovanov jestvuje l’ud, ktorý je spomedzi Grékov krest’anský; nazývajú ich Nandar. Títo sú síce početnejší než Mad’ari, ale sú slabší. Pokial' ide o tie dve rieky, jedna sa nazýva Itil a druhá Duna. Ked' sa Mad’ari zdržujú na brehu rieky, vidia proti sebe Nandazov" (Ratkoš 1964: 324). Etnikum Nandor stotožňuje P. Ratkoš so starými Bulharmi, mad’arskú podobu názvu Dunaj, ktorú použil Gardízí odôvodňuje P. Ratkoš slovami: „Podl’a našej mienky táto veta Gardízího textu čerpá z prameňa, blízkeho mad'arskému prostrediu..." (Ratkoš 1964: 324, pozn. č. 5). Stredoveké listiny dochovávajú podoby rieky Dunaj rozlične - latinsky Danubius, nemecky Donau, mad'arsky Duna (Hladký - Závodný 2015: 111). Vo všeobecnosti sa jazykovedci zhodujú v názore, že názov Dunaj vznikol z indoeurópskeho základu *danu vo význame „voda, prúd, rieka“ (Lutterer - Majtán - Šrámek 1982: 91). J. Hladký a A. Závodný pripomínajú, že „Z pôvodného indoeurópskeho základu *danu sa v slovanských jazykoch vyvinuli dve apelatívne formy - *dunavb (v macedónčine, bulharčine a starej ukrajinčine) a dunajb (v slovinčine, češtine, slovenčine, pol'štine, ruštine, ukrajinčine i bieloruštine), obidve formy sú známe v srbčine a chorvátčine. Obidve podoby majú v jednotlivých jazykoch rôzne významové odtienky - hlboká voda, vel'ká rieka, stojatá hlboká voda, žriedlo, na vodu bohatý tok, prameň vyvierajúci spod zeme, jazero“ (Hladký - Závodný 2015: 111). Hydronymum Dunaj sa v slovenských (a českých) nárečiach apelativizovalo vo význame „voda, potok, bystrina“, ako o tom svedčia názvy Dunajec, osada Dunajov, ktoré boli motivované apelatívom dunaj. Samotné apelatívum vo význame „voda“ je dochované v l'udovej frazeológii a rozprávkach (pozri Hladký - Závodný 2015: 111).

Významným európskym vodným tokom je rieka Tisa $(1358 \mathrm{~km})$, ktorá pramení na Ukrajine, preteká cez Ukrajinu, Rumunsko, Mad’arsko, Slovensko, Srbsko a pri Novom Sade ústi do Dunaja. Územím Slovenska preteká len v dížke $5 \mathrm{~km}$ a tvorí hranicu medzi Mad’arskou a Slovenskou republikou. Najstarší zápis rieky Tisy, ktorá je významným 
l'avostranným prítokom Dunaja, je uvedený v gréckej a latinskej podobe ako Pathissus, Tisia (Varsik 1989: 86), Neskorší zápis pochádza z pera neskororímskeho spisovatel’a Jordana, ktorý žil v 6. storočí nášho letopočtu. Jordanes zapísal túto rieku ako Tisia. Existencia názvu z obdobia pred príchodom Slovanov na územie dnešného Slovenska je svedectvom, že názov je predslovanského pôvodu, má však indoeurópsky pôvod, pretože $\mathrm{v}$ doterajších názoroch o pôvode názvu existuje zhoda, že názov vznikol z indoeurópskeho koreňa *ti- vo význame „topit’, topit’ sa“, pravdepodobne s preneseným významom „bahnitá rieka“ (pozri Lutterer - Majtán - Šrámek 1982: 303). Indoeurópsky koreň zároveň vylučuje motiváciu porastom tisu v jej okolí. Ako pripomína historik B. Varsik „Slovania prevzali názov od predslovanského obyvatel'stva a Mad’ari ho zasa prevzali od Slovanov. V čase príchodu Mad’arov do Karpatskej kotliny oblast' územia pri hornej Tise bola obývaná západoslovanským obyvatel'mi, predkami dnešných východných Slovákov, od ktorých názov prevzali Mad’ari.“(Varsik 1989: 86)

Ďalším tokom, ktorého názov patrí medzi predslovanské, je $329 \mathrm{~km}$ dlhá rieka Morava prameniaca v Českej republike, tvoriaca na dolnom toku (od obce Rohatec) prirodzenú $48 \mathrm{~km}$ dlhú hranicu medzi Českom a Slovenskom; od ústia rieky Dyje (pri Hohenau) po ústie Moravy do Dunaja utvára zasa 71 km dlhú hranicu Slovenska s Rakúskom (Závodný 2012: 195). Najstaršie názvy tohto vodného toku uvádza už Plínius Starší (23 - 79 n. 1.) vo forme Maro, Tacitus (asi 55 - asi 117 n. 1.) ju zapísal ako Marus. Z uhorských dejín máme zápisy od Anonyma z roku 1200 - fluv. Moroua, 1231 fluv. Morowa. Tieto zápisy sú však už z obdobia po usídlení Slovanov.

Staršie etymológie názvu Morava prehl’adne spracoval V. Šmilauer (1932: 289 290). Pôvod názvu a motivácia sa nedajú spol’ahlivo určit'. V. Šmilauer (1932) vo svojich názoroch vychádzal predovšetkým z E. Schwarza, ktorý za východisko názvu pokladá indoeurópsky koreň *mar- vo význame „voda“. V. Šmilauer pripomína aj iné etymológie - H. Krahe považuje názov za ilýrsky, Mladenov za starotrácky, A. A. Šachmatov hladal východisko v keltčine. Podl’a V. Šmilauera Germáni názov priklonili k domácemu *mari, čo znamenalo „plytká, stojatá voda, močiar“ a dali mu formu Mar- -ahwa > Maraha, Marcha. Prípona - ahwa označovala u Germánov vodu. Slovania prispôsobili názov k domácemu morava vo význame „lúka, trávnaté miesto“. Tento vývin je podla V. Šmilauera pravdepodobnejší ako hláskový vývin Marahva > Morava ako predpokladá Melich. B. Varsik $(1989: 18,96)$ považuje názov Morava za predslovanský a pripúšs’a, že zakončenie -ava dostávali nielen názvy riek, ktorých základ bol bezpečne slovanského pôvodu (ako boli Olšava, Jelšava, Trnava, Rudava, Myslava a pod.), ale aj také názvy, ktorých základ bol predslovanského pôvodu (Marus - Morava, r. 892 Maraha < *Marahwa, z ktorého sa mohol vyvinút' aj nemecký názov March). Názov Morava má podl’a názorov viacerých jazykovedcov ešte predkeltský pôvod s významom „,voda, močiar“. Slovenské, či slovanské apelatívum morava (vo význame „močiar, tráva na močiari, zatopené územie, luh") nie je motivantom názvu rieky, pretože je mladšie.

Najdlhšou riekou prameniacou i ústiacou na území Slovenska je rieka Váh, ktorá meria $365 \mathrm{~km}$. Etymológie tohto názvu nie sú dodnes jednoznačné a jasné. Logickejšie argumenty uvádzajú zástancovia predslovankého pôvodu názvu (napr. E. Schwarz, V. Šmilauer, B. Varsik a d’alší), ktorí pôvod názvu vidia v germánskom wâg vo význame 
prúd. Historik B. Varsik tieto názory podporuje logickým tvrdením, že názvy vel'kých vodných tokov musia pochádzat' od obyvatel'ov, ktorí tu žili pred príchodom Slovanov a tieto názvy Slovania od nich prevzali a adaptovali do svojho jazyka. Žial', najstaršie doteraz nájdené zápisy Váhu pochádzajú zo začiatku 12. storočia (1111 flumen Vvaga, 1113 aqua $V v a c$ ), teda z obdobia prítomnosti Slovanov v tomto priestore. Ked’že pri vel'kých tokoch riek boli pre obyvatel'stvo výhodnejšie a lepšie životné podmienky, a vieme, že územie Slovenska bolo pred príchodom Slovanov osídlené „germánskym a možno aj predgermánskym obyvatel'stvom, najmä keltského pôvodu“ (Varsik 1989: 22), je pravdepodobné, že Slovania prevzali od nich názov rieky Váh.

V. Šmilauer považuje názov Váh za germánsky: „Dnes obecně se vykládá jméno Váhu z germánčiny. Základem je germánske *wâg ,bewegtes Wasser, Woge, Strom, Fluss`(Šmilauer 1932: 307). Tento predslovanský - germánsky (kvádsky) názov prevzali, podl'a V. Šmilauera, Slovania vo forme Wág a od nich potom Mad’ari.

V. Šmilauer takisto sumarizuje predchádzajúce etymológie Váhu, pričom ich delí na etymológie vychádzajúce zo sanskrtu (Veterán), latinské (Matej Bel), slovanské (Bel, Hunfalvy, Sasinek, Tomicki, Zoch), sarmatské (Sobolevskij) a mad’arské (Podhráczky) - (Šmilauer 1932: 307).

Významný slovenský učenec 18. storočia Matej Bel vo svojich Notíciách sa zaoberal s myšlienkou odvodit' a vysvetlit' pomenovanie Váh zo slovenského apelatíva váha alebo z latinského vagus (túlavý), napokon meno rieky odvodzuje od nemeckého slova die Woge - vlna, príval. „Je totiž nadmieru zvlnený a prudký, najmä v tých miestach, kde skaly a bralá robia koryto hrbol’atým. Vtedy totiž rozbitý jedným úskalím rúti sa do druhého a zas naspät' odrazený môže robit' dojem, že ani tak netečie, ako skôr sa len vlní“ (Drdoš 1984: 81-82).

Podl'a jazykovedca a slavistu J. Stanislava je pomenovanie Váh nemecké s významom „rieka“" (Stanislav 1947: 68). Od roku 1972 prichádza predovšetkým Š. Ondruš s viacerými verziami o slovanskom, resp. slovenskom pôvode názvu Váh.

Druhá najdlhšia rieka na Slovensku je rieka Hron $(271 \mathrm{~km})$. Je to jediný vodný tok na Slovensku, ktorého názov je bezpochyby predslovanský, pretože najstarší zápis pochádza z pera rímskeho cisára Marca Aurélia, ktorý v diele Ta eis heauton spomína miesto bojov proti germánskym kmeňom Markomanov a Kvádov na severnej strane dunajskej línie. Miesto bojov lokalizoval v oblasti rieky Granova. Najstarším dokladom je teda zápis Granova pochádzajúca z rokov 166 - 180. V. Šmilauer (1932: 350) sa pri výklade názvu Hron priklonil ku germánskej etymológii E. Schwarza zo staronemeckého *Gran-ahwa (sthn. gran - smrek, ahwa - voda). Okrem tejto etymológie sumarizuje V. Šmilauer aj d’alšie výklady, medzi ktorými uvádza napr. názory o ilýrskom pôvode názvu J. Loewenthala - z panónskeho *granuuá, či starohornonemeckého krammr - vlhký. G. Czirbusz uvádzal keltský etymón gronve - lúčna rieka, neskôr pripúšt’a germánsky pôvod názvu - zo starohornonemeckého výrazu gruoni - zelený. Popri ilýrsky, germánskych a keltských východiskách sa snažili názov Hron odvodit’ aj zo slovanských, či slovenských základov (pozri Šmilauer 1932: 350).

Dôležitou slovenskou riekou je Hornád s celkovou dížkou $286 \mathrm{~km}$, ktorý preteká dvomi štátmi - po $193 \mathrm{~km}$ opúšt’a slovenské územie a v Mad’arsku ústi do Slanej. 
Hornád odvodňuje najväčšiu západnú čast' východného Slovenska. Aj názov rieky Hornád ponúka viacero interpretácií, medzi ktorými sú aj etymológie vychádzajúce z predslovanských základov. Najstaršie historické zápisy Hornádu pochádzajú až zo začiatku 13. storočia - v roku 1200 je zapísaný ako fl. Honrat, Honrad, roku 1230 ho listiny spomínajú v podobe $f$. Harrad, roku $1232 f$ l. Homad, Hornad atd'. Pre interpretáciu pôvodného lexikálneho východiska, či ide o slovanské alebo predslovanské apelatívum, je dôležité, že nemáme dochovanú podobu s $g$ (teda ${ }^{*}$ Gonrad). Nepredpokladáme, že názov pochádza z mad’arčiny, pretože územie povodia Hornádu obsadili najprv prichádzajúci Slovania a až o niekol'ko storočí sa dostávajú na územie jeho dolného toku mad’arské kmene, ktoré sa postupne posúvajú aj na sever, teda do strednej časti Hornádu. Keby sme pripustili slovanskú motiváciu, napriek tomu, že zápis je až zo začiatku 13. storočia, teda $\mathrm{z}$ obdobia, $\mathrm{v}$ ktorom už prebehla zmena $\mathrm{g}>\mathrm{h}$, mad'arčina by pôvodnú podobu určite dochovala, podobne ako je tomu pri hydronymách Váh - mad’arsky Vág, Hron - mad'arsky Garam atd'.

Pôvodom názvu Hornád sa zaoberal už Anonymus, z pera ktorého pochádzajú dva najstaršie názvy Honrat, Honrad a podl’a jeho názoru názov existoval už pred príchodom Mad'arov do povodia hornej Tisy, čím vylúčil pôvod z mad’arčiny. Ďalší historici a jazykovedci sa zaoberali teóriami o latinskom pôvode - napríklad J. Hradszký predpokladal, že podoba fluvius Conradi znamená Konradovu rieku, čo by však nedokazovalo jej latinský pôvod. Viaceré etymológie sa prikláňali ku germánskemu (teda predslovanskému) pôvodu - napríklad mad’arský akademik S. Borovszky uvažoval o germánskom prapôvode názvu, pričom za východiskový tvar považoval podobu hornath - rohovitý, oblúkovitý, čo by prenesene znamenalo, že rieka má kl'ukaté koryto. J. Melich sa v roku 1917 pokúsil vysvetlit’ pôvod názvu vývinovou relatívnou chronológiou, pričom predpokladal takéto podoby: Chonrád/Chonrát $>$ Honrád/Honrát; Chornád/Chornád $>$ Hornád/Hornát $>$ Harnád/Harnát $>$ Hërnád/Hërnát $>$ Hernád/Hernát. Z mad'arského tvaru Honrád vznikla slovanská podoba Hornád, z prvotnej podoby Chonrát sa utvoril nemecký tvar Kunert, latinský variant Conrada má podl'a neho pôvod v podobe Chonrád. Nemecké varianty Chonrad a Chornad sa snažil vysvetlit’ J. Štolc (1951), ktorý ich pôvod vysvetl'oval z nemeckých foriem Corrad, Conrada, Kunrad, ale tieto podoby záviseli od národnosti pisára. J. Štolc však reprezentuje skupinu názorov, že názov Hornád je slovanského pôvodu a k etymológii sa dostal kritikou názoru J. Martinku, ktorý pri výklade hydronyma vychádzal z praslovanského základu *gъrnъ, ktorý sa po zmene $\mathrm{g}>\mathrm{h}$ zmenil na základ hrn- (> hrnút') (podrobné interpretácie pozri v diele Goótšová/Chomová/Krško 2014: 167-168).

Najväčším l'avostranným prítokom Váhu je rieka Nitra (168,5km). Najstaršie zápisy Nitry pochádzajú až z obdobia prítomnosti Slovanov v tejto oblasti - názov flumen Nittra pochádza z roku 1006, takisto aj podoby minoris fluminis Nittra, maioris fluminis Nitra, zápis z roku 1113 uvádza túto rieku ako aqua Nitria, Nittria, Nitra, Nittra atd’. (Hladký 2004: 159).

V. Šmilauer vo svojom Vodopise starého Slovenska (1932: 338) zosumarizoval všetky dovtedajšie etymologické výklady tohto hydronyma, pričom ich rozdelil do troch skupín. Za slovanský pôvod sa vo viacerých štúdiách vyslovili napr. F. Umlauft 
(1886) a G. Czirbusz (1908, ten sa vyslovil aj za germánsky pôvod z nem. koreňa *nit„stiesnený“, aar „voda“). Názov odvodzovali od slova *vъn-o(N)trb > vnutro, nutro s motiváciou „rieka tečúca vo vnútri, medzi štyrmi riekami“. T. Tomicki v roku 1925 rekonštruoval pôvodný tvar vo forme *Nitorna, Nutorna. J. Červinka v roku 1928 v názve Nitra videl slovanský pôvod, ale samotné východiskové meno pokladal za nejasné, no dával ho do súvislosti s osobným menom Nitrabor a baltoslovanským apelatívom nitra ,zástava“.

Dlhšiu dobu sa pôvodom názvu Nitra zaoberal Š. Ondruš, ktorý predpokladal indoeurópsky pôvod názvu, ale primárne dokazoval jeho praslovanský pôvod. K výkladu Š. Ondruša sa prikláňa aj J. Hladký v monografii Hydronymia povodia Nitry (2004: 147).

B. Varsik (1989), podobne ako iní bádatelia, predpokladá, že v prípade názvu Nitra ide o predslovanský základ a Ondrušove teórie spochybňuje najmä tým, že listiny do 9 . až 11 . storočia sú v prevažnej miere falzá.

K ostatným teóriám o predslovanskom pôvode hydronyma Nitra patrí teória R. Krajčoviča (2005: 18-20). Podl'a nej názov rieky (aj lokality Nitra) odráža napätú včasnoslovansko-kvádsku symbiózu z prelomu 4. a 5. storočia. Vo svojom výklade sa opiera o podoby predslovanských germánskych názvov mesta (Neiter, Neuter, Neutra), ktoré museli vzniknút' len z latinsko-rímskeho spojenia Neui-iter, pričom iter znamená „cesta, pochod“, ale aj „tok, rieka“ s prívlastkom novi-us s významom „to, čo je za hranicou“. Podl'a R. Krajčoviča, šlo o orientačno-informačný názov pre rímske légie a skrátenú podobu Neuiter prevzali naši predkovia od zvyšku rímskych osadníkov, ktorí zastali v oblasti po stiahnutí sa rímskych légií. „V prostredí staroslovenských osadníkov prevzaté slovné spojenie Neuiter sa po zániku medzisamohláskového - $u$-zmenilo na Neiter a z tejto podoby po zákonitej zmene psl. slabík na slabiky otvorené, t. j. so samohláskou na konci slabiky v spojení Nei- sa zmenilo na Ni- a -ter na -tra." (Krajčovič 2005: 20)

L'avostranný prítok Dunaja - rieka Ipel' (232,5 km) odvodňuje vel'kú čast' stredného Slovenska (predovšetkým bývalú novohradskú a hontiansku župu). Najstaršie dochované doklady pochádzajú zo začiatku 12. storočia - 1135 Ipul, 1138 fl. Ipul, Ipol, 1236 fl. Ypul, Ipul, Ipol atd' (Majtán/Žigo 1999: 28). Preto väčšina teórií poukazuje na slovanský základ (tak aj autori monografie Hydronymia povodia Ipl'a). V. Šmilauer (1932) zhrnul dovtedajšie teórie o pôvode názvu Ipel’ a rozdelil ich na slovanské, germánske (Borovszky odvodzoval názov zo starohornonemeckého aphol - podobne Apfelbach teda vodný tok pretekajúci porastom divých jabloní). Ďalšiu skupinu tvorili etymológie neznáme, pravdepodobne ilýrske (Šmilauer 1932: 361).

R. Krajčovič (2005) prišiel s teóriou o predslovanskom pôvode názvu Ipel' a dáva ho do súvislosti s pobytom rímskych légií na našom území. Opiera sa predovšetkým o archeologické nálezy rímskych artefaktov z oblasti Ipl'a (Dudince, Želovce, Prša...). Podla R. Krajčoviča bolo východisko názvu latinsko-rímske adjektívum hippulius, ktoré vzniklo zo substantíva hippe vo význame kôň. „Prví slovienski osadníci prevzali od zvyškov rímskych osadníkov, korí v oblasti Ipl'a zostali po odchode rímskych légií, latinsko-rímsky záznam o ceste vedúcej popri pravom brehu Ipl'a zrejme v tvare adjektíva zo spojenia hippulia via vo význame jazdecká cesta a z adjektíva hippulia sa začala v 
prostredí našich predkov formovat' dnešná podoba názvu Ipel““ (Krajčovič 2005: 22). Ďalšie hláskové úpravy výrazu vyplývali z vtedajšieho stavu jazyka - počiatočné $h$ sa odstránilo, pretože $\mathrm{v}$ tom čase naši predkovia ešte nepoznali túto hlásku, vokály $u$ a $i \mathrm{v}$ tvare Ipuli sa zmenili podl'a zákonitostí jazyka na jery, ktoré sa neskôr dali podobu Ipъlb.

Územie strednej Európy bola už pred príchodom Slovanov dôležitým priestorom, ktorým prechádzali mnohé etniká, prípadne tu trvalo žili. O kontaktoch našich predkov s týmito etnikami svedčia aj viaceré názvy významných európskych vodných tokov. Viaceré hydronymá majú keltský, gótsky, kvádsky pôvod. Pri indoeurópskych východiskách (napr. pri riekach Dunaj, Tisa, Morava) sa dá uvažovat' o tom, že názov vznikol v jazykoch etník, ktoré obývali územie pred príchodom predkov, prípadne, že názov sa vyvinul paralelne u Slovanov.

\section{Literatúra}

DRDOŠ, Ján (1984) Matej Bel slovenský geograf. Bratislava: Veda.

BYSTRICKÝ, Peter (2008) Stahovanie národov (454-568). Ostrogóti, Gepidi, Longobardi a Slovania. Bratislava: Občianske združenie Spoločnost' PRO HISTORIA.

ČAPLOVIČ, Dušan (1998) Včasnostredoveké osídlenie Slovenska. Bratislava: Academic Electronic Press.

FUSEK, Gabriel (2002) „Včasnoslovanské odobie.“ In: A. Ruttkay, M. Ruttkay, P. Šalkovský (eds.), Slovensko vo včasnom stredoveku. Nitra: Archeologický ústav SAV Nitra, 23-27.

GERLAKOVÁ, Alexandra (2008) „Odraz osídlenia severného Šariša v pomenovaniach riek z povodia Torysy.“ In: V. P. Polách (ed.), Svět za slovy a jejich tvary, svět za spojením slov. Olomouc: Univerzita Palackého, 2008, 67-73.

GOÓTŠOVÁ, Andrea/Alexandra CHOMOVÁ/Jaromír KRŠKO (2014) Hydronymia slovenskej časti povodia Hornádu. Banská Bystrica: Vydavatel'stvo Univerzity Mateja Univerzity v Banskej Bystrici - Belianum, Filozofická fakulta.

CHOMOVÁ, Alexandra (2010) „K hydronymii povodia Torysy. (K variantnosti a polyonymii v pomenovaní tokov z povodia Torysy).“ In: J. David (ed.), Mnohotvárnost a specifičnost onomastiky. IV. česká onomastická konference. 15. - 17. zář́i 2009, Ostrava. Sbornik přispěvků. Ostrava/Praha: Filozofická fakulta Ostravské univerzity v Ostravě/Ústav pro jazyk český AV ČR, v. v. i., 198-205.

HLADKÝ, Juraj (2004) Hydronymia povodia Nitry. Trnava: Trnavská univerzita Pedagogická fakulta.

HLADKÝ, Juraj (2011) Hydronymia povodia Dudváhu. Trnava: TYPI UNIVERSITATIS TYRNAVIENSIS a VEDA.

HLADKÝ, Juraj/Andrej ZÁVODNÝ (2015) Hydronymia Žitného ostrova. Trnava: TYPI UNIVERSITATIS TYRNAVIENSIS a VEDA.

KRAJČOVIČ, Rudolf (2005) Živé kroniky slovenských dejín skryté v názvoch obcí a miest. Bratislava: Literárne informačné centrum. 
KRŠKO, Jaromír (2008) Hydronymia povodia Hrona. Banská Bystrica: Univerzita Mateja Bela, Fakulta humanitných vied.

KRŠKO, Jaromír/Drahomír VELIČKA (2011) Hydronymia povodia Kysuce. Banská Bystrica: Univerzita Mateja Bela, Fakulta humanitných vied.

KRŠKO, Jaromír (2011) Hydronymia horného povodia Váhu (od povodia Rajčanky po prameň Váhu). Banská Bystrica: Univerzita Mateja Bela, Fakulta humanitných vied.

LUTTERER, Ivan/Milan MAJTÁN/Rudolf ŠRÁMEK (1982) Zeměpisná jména Československa. Praha: Mladá fronta.

MAJTÁN, Milan/Kazimierz RYMUT (1998) Gewässernamen im Flussgebiet des Dunajec. (Nazwy wodne dorzecza Dunajca). Stuttgart: Franz Steiner Verlag. (Hydronymia Europaea, 13).

MAJTÁN, Milan/Pavol ŽIGO (1999) Hydronymia povodia Ipla. Bratislava: Jazykovedný ústav L. Štúra SAV, Filozofická fakulta UK.

MAJTÁN, Milan/Kazimierz RYMUT (2006) Hydronymia povodia Oravy. Bratislava: Veda.

ONDRUŠ, Šimon (2000) „Slovak Hydronymy.“ In: M. Kučera (ed.), Slovaks in the central Danubian region in the $5^{\text {th }}$ to $11^{\text {th }}$ century. Bratislava: Slovenské národné múzeum, 2000, 185-215.

RYMUT, Kazimierz/MAJTÁN, Milan (1998) Gewässernamen im Flussgebiet des Dunajec (Nazwy wodne dorzecza Dunajca). Stuttgart: Franz Steiner Verlag.

SIČÁKOVÁ, Luba (1996) Hydronymia slovenskej časti povodia Slanej. Prešov: Pedagogická fakulta UPJŠ.

PIETA, Karol (2002) „Osídlenie Slovenska v dobe st’ahovania národov.“ In: A. Ruttkay, M. Ruttkay, P. Šalkovský (eds.), Slovensko vo včasnom stredoveku. Nitra: Archeologický ústav SAV Nitra, 2002, 11-22.

RATKOŠ, Peter (1964) Pramene k dejinám Vel'kej Moravy. Bratislava: Vydavatel'stvo SAV.

RATKOŠ, Peter (1965) „Problematika raného feudalizmu.“ In: P. Ratkoš (ed.), O počiatkoch slovenských dejín. Sbornik materiálov. Bratislava: Vydavatel'stvo SAV, 7-19.

STANISLAV, Ján (1947) Odkryté mená slovenských miest a dedín. Bratislava: Orlovský.

STANISLAV, Ján (1999) Slovenský juh v stredoveku. I. Bratislava: Národné literárne centrum - Dom slovenskej literatúry.

STANISLAV, Ján (2004) Slovenský juh v stredoveku. Slovník mien s mapovými prílohami. II. Bratislava: Literárne informačné centrum.

ŠMILAUER, Vladimír (1932) Vodopis starého Slovenska. Praha - Bratislava: Nákladem Učené společnosti Šafař́íkovy.

VARSIK, Branislav (1989) Slovanské (slovenské) názvy riek na Slovensku a ich prevzatie Mad'armi v 10.-12. storočí. Bratislava: Veda.

ZÁVODNÝ, Andrej (2012) Hydronymia slovenskej časti povodia Moravy. Trnava: TYPI UNIVERSITATIS TYRNAVIENSIS. 


\section{Resumé \\ VPLYV PREDSLOVANSKÝCH KONTAKTOV NA HYDRONYMIU SLOVENSKA}

V príspevku venujeme pozornost' vplyvu predslovanských etník na hydronymiu dnešného Slovenska. Migrácia celých etnických skupín - najmä po rozpade Rímskej ríše, viedla ku vzájomným kontaktom medzi pôvodným a prichádzajúcim obyvatel'stvom. Etnické kontakty mali vplyv aj na jazyky týchto etník, dochádzalo k vzájomnému ovplyvňovaniu a preberaniu časti lexiky. Prichádzajúce etniká sa museli orientovat' $\mathrm{v}$ novom prostredí, museli identifikovat' a diferencovat' dôležité orientačné body, medzi ktoré patria predovšetkým vrchy, pohoria a vodné toky.

Problematiku predslovanských hydroným môžeme sledovat' $\mathrm{z}$ dvoch uhlov pohl'adu - 1. analyzovat' názvy dochované z obdobia pred príchodom Slovanov na územie Slovenska; 2. analyzovat' názvy, ktorých pôvod niektorí autori pokladajú za predslovanský.

Najstarší názov rieky z oblasti Slovenska, ktorý je bezpečne z obdobia pred príchodom Slovanov, zapísal rímsky cisár Markus Aurélius v rokoch 166 - 180 ako Granoua. Ide o zápis rieky Hron, pri ktorej bojovali rímske légie proti germánskym kmeňom Markomanov a Kvádov. Viacerí historici a jazykovedci sa domnievajú, že nielen rieky Dunaj, Morava a Tisa majú predslovanský pôvod, ale aj d’alšie názvy vel'kých riek vznikli už pred príchodom Slovanov do oblasti strednej Európy. V príspevku analyzujeme názvy Dunaj, Morava, Váh, Hron, Tisa, Nitra a Hornád.

Kl'účové slová: onomastika, hydronymia, predslovanské hydronymá, slovenské rieky, etnické kontakty

\section{Abstract \\ THE INFLUENCE OF PRE-SLAVIC ETHNIC GROUPS ON THE HYDRONYMY OF PRESENT-DAY SLOVAKIA}

In this paper, we focus on the influence of pre-Slavic ethnic groups on the hydronymy of present-day Slovakia. The migration of entire ethnic groups - especially after the dissolution of the Roman Empire - led to contact between native and incoming people. Ethnic contact also affected languages of these ethnic groups, as mutual influencing and borrowing of vocabulary occurred. Incoming ethnic groups had to find their way around in the new surroundings as well as identify and distinguish important landmarks, mainly hills, mountains and streams.

We can approach the issue of pre-Slavic hydronyms from two points of view: one, by analyzing the names preserved from the time period before the arrival of Slavs in the territory of Slovakia, and two, by analyzing the names whose origin some authors consider to be pre-Slavic.

The oldest name of a river from the Slovak region comes from the time period before the arrival of the Slavs. It was recorded by the Roman emperor Marcus Aurelius in 
years 166-180 AD as Granoua. It is a record of the river Hron at which Roman legions fought against the Germanic tribes of the Marcomanni and Quadi. Several historians and linguists believe that besides the rivers Dunaj, Morava and Tisa, other names of big rivers date from before the arrival of Slavs in the central Europe. In the paper, we analyse the names Dunaj, Morava, Váh, Hron, Tisa, Nitra and Hornád.

Keywords: onomastics, hydronymy, Pre-Slavic hydronymy, Slovak rivers, ethnic contacts

\section{Povzetek}

\section{VPLIV PREDSLOVANSKIH STIKOV NA HIDRONIMIJO SLOVAŠKE}

V prispevku namenjamo pozornost vplivu predslovanskih etnosov na hidronimijo današnje Slovaške. Migracija celih etničnih skupin, posebno po razpadu Rimskega cesarstva, je pripeljala do vzajemnih stikov med staroselskim in prihajajočim prebivalstvom. Etnični stiki so vplivali tudi na jezike teh ljudstev, prihajalo je do medsebojnega vplivanja in prevzemanja dela leksike. Prihajajoča ljudstva so se morala v novem prostoru orientirati, morala so določiti in razlikovati pomembne orientacijske točke, med katere spadajo predvsem vrhovi, pogorja in vodni tokovi.

Problematiko predslovanskh hidronimov lahko raziskujemo z dveh vidikov: 1. da analiziramo imena, ohranjena iz obdobja pred prihodom Slovanov na ozemlje Slovaške; 2. da analiziramo imena, ki jih nekateri avtorji štejejo za predslovanska.

Najstarejše rečno ime s področja Slovaške, ki je zagotovo iz obdobja pred prihodom Slovanov, je zapisal rimski cesar Mark Avrelij v letih 166-180 kot Granoua. Gre za zapis reke Hron, pri kateri so se rimske legije bojevale proti germanskim plemenom Markomanov in Kvadov. Več zgodovinarjev in jezikoslovcev domneva, da predslovanskega izvora niso le Donava (slovaško Dunaj), Morava in Tisa, temveč da so tudi druga imena večjih rek nastala že pred prihodom Slovanov v srednjo Evropo. V prispevku analiziramo imena Dunaj (= Donava), Morava, Váh, Hron, Tisa, Nitra in Hornád.

Ključne besede: onomastika, hidronimija, predslovanska hidronimija, slovaške reke, etnični stiki 